\title{
The value of microvolt T-wave alternans in the diagnosis of reversible myocardial ischemia in patients without structural cardiac disease
}

\section{Mislav Puljević*, Joško Bulum, Aleksander Ernst, Davor Miličić, Davor Puljević}

University of Zagreb School of Medicine, University Hospital Centre Zagreb, Zagreb, Croatia
RECEIVED:

July 16, 2015

ACCEPTED:

September 17, 2015



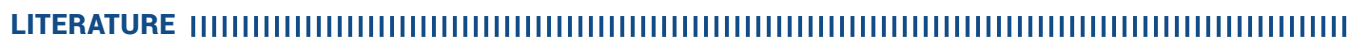

1. Issa Z, Miller J. Molecular mechanisms of cardiac electric activity, In: Issa Z, Zippes D, ed. Clinical Arrhythmology and Electrophysiology: A Companion to Braunwald's Heart Disease, Expert Consult. Philadelphia: WB Saunders, 2012, 1-9.

2. Task Force Members, Montalescot G, Sechtem U, Achenbach S, Andreotti F, Arden C, et al. 2013 ESC guidelines on the management of stable coronary artery disease: the Task Force on the management of stable coronary artery disease of the European Society of Cardiology. Eur Heart J. 2013;34(38):2949-3003. DOI: http://dx.doi.org/10.1093/eurheartj/eht296

3. Haghjoo M, Arya A, Sadr-Ameli MA. Microvolt T-wave alternans: a review of techniques, interpretation, utility, clinical studies, and future perspectives. Int J Cardiol. 2006;109:293-306. DOI: http://dx.doi.org/10.1016/j.ijcard.2005.06.049 